\title{
KETIMPANGAN DAN FAKTOR-FAKTOR YANG MEMPENGARUHI KUALITAS PEMBANGUNAN MANUSIA DI KOTA DEPOK
}

\author{
Disparity and Factors Influence the Quality of Human Development in Depok
}

\author{
Dewi Nur Aini ${ }^{1}$, Harianto ${ }^{2}$, Herien Puspitawati ${ }^{3}$ \\ 1Staff Badan Pengawasan Keuangan dan Pembangunan (BPKP) Pusat. Email: dewinuraini88@gmail.com \\ 2 Staff Pengajar Departemen Ilmu Ekonomi, Fakultas Ekonomi dan Manajemen IPB \\ Email: harianto@gmail.com, \\ ${ }^{3}$ Staff Pengajar Departemen Ilmu Keluarga dan Konsumen, Fakultas Ekologi Manusia IPB \\ Email: puspitawatiherien@gmail.com
}

\begin{abstract}
Human Development Index (HDI) of Depok is highest in West Java, but there are inequality and the gender gap. The purposes of the research are to analyze the level of income inequality, analyze the level of economic progress and analyze the factors that affect of HDI. The data were analyzed using Williamson Index, Klassen typology and panel regression using data from 11 districts in Depok over the period 2012-2014. Based on Williamson Index, we found that disparity of income among districts in Depok is relatively high $(>0,5)$ but tended to decrease over the period of 2013-2014. Klassen typology shows that Depok can be classified into four types. Estimation using fixed effect model could be applied to examined the impact of independent variables consist of education aspects, health aspects, personal income aspects and demography aspect to HDI. Regression analysis showed a positive and significant influence between the number of primary schools, PDRB per capita and population density with IPM. The ratio of teachers and students in primary schools and the ratio of teachers and students in high school/vocational negative significant effect on the HDI.
\end{abstract}

Keyword: HDI, disparity, panel data

\begin{abstract}
Indeks Pembangunan Manusia (IPM) Kota Depok tertinggi di Jawa Barat, tetapi ada ketimpangan dan kesenjangan gender. Tujuan penelitian ini adalah untuk menganalisis tingkat ketimpangan pendapatan, menganalisis tingkat kemajuan ekonomi dan menganalisis faktor-faktor yang mempengaruhi IPM. Data dianalisis dengan menggunakan Indeks Williamson, tipologi Klassen dan regresi data panel menggunakan data dari 11 kecamatan di Depok selama periode 2012-2014. Berdasarkan Indeks Williamson, kami menemukan bahwa disparitas pendapatan antar kecamatan di Depok relatif tinggi $(>0,5)$, tetapi cenderung menurun selama periode 2013-2014. Tipologi Klassen mengklasifikasikan Kota Depok menjadi empat kuadran. Estimasi dengan menggunakan model efek tetap bisa diterapkan untuk meneliti dampak dari variabel independen meliputi aspek pendidikan, aspek kesehatan, aspek pendapatan pribadi dan aspek demografi terhadap IPM. Hasil analisis regresi menunjukkan pengaruh positif dan signifikan antara jumlah sekolah dasar, PDRB per kapita dan kepadatan penduduk dengan IPM. Rasio guru dan murid di sekolah dasar dan rasio guru dan murid sekolah menengah atas/kejuruan berpengaruh negatif dan signifikan terhadap IPM.
\end{abstract}

Kata kunci: IPM, disparitas, data panel

\section{PENDAHULUAN}

Paradigma pembangunan manusia menjadi isu yang hangat dibicarakan hingga saat ini (Ranis 2004). Di era keterbukaan dan kompetisi, diperlukan potensi untuk mampu bersaing dengan bangsa lain. Daya saing yang dikelola dengan baik membawa konsekuensi meningkatnya kualitas hidup manusia (Ulengin 2011). United Nations Development Programme menggunakan $\begin{array}{lrr}\text { Indeks } & \text { Pembangunan } & \text { Manusia } \\ \text { untuk } & \text { mengukur } & \text { keberhasilan }\end{array}$ pembangunan manusia. Kebijakan yang fokus pada pembangunan manusia memainkan peran penting dalam pembangunan yang berkelanjutan, karena dampak langsung dan efek umpan balik dalam mempertahankan pertumbuhan ekonomi (Suri et al. 2011), namun kesenjangan gender di bidang pendidikan dan pekerjaan berakibat pada menurunkan 
pertumbuhan ekonomi (Klassen and Lamanna 2009).

Pencapaian IPM Kota Depok sebesar 80.14 pada tahun 2013, meraih peringkat tertinggi se-Provinsi Jawa Barat dan peringkat ke empat nasional. Tingginya IPM Kota Depok menunjukkan bahwa tingkat kesejahteraan masyarakat Kota Depok relatif baik, namun secara kewilayahan menunjukkan adanya kesenjangan diantara kecamatan yang ada (Situmorang 2011). Keberhasilan pembangunan sumberdaya manusia belum diikuti dengan keberhasilan pembangunan gender yang diukur dengan Indeks Pembangunan Gender (IPG). Rasio antara IPG dengan IPM berfluktuasi di seputar 91.43 dan berada dibawah rasio nasional sebesar 94.25. Pengukuran keberhasilan kualitas pembangunan manusia melalui IPM belum cukup efektif memperkecil kesenjangan antara laki-laki dan perempuan dalam pencapaian kapabilitas dasar di bidang kesehatan, pendidikan, dan ekonomi (KPPPA 2014).

Kesenjangan merupakan tantangan pembangunan berkelanjutan di sebagian besar negara (Shankar and Anwar 2003) dan menjadi tantangan terkini pembangunan daerah (Pito 2013). Strategi alokasi anggaran yang tepat dapat mendorong dan mempercepat pertumbuhan ekonomi sekaligus menjadi alat untuk mengurangi kesenjangan/ ketimpangan regional (Kuncoro 2004).

Berdasarkan uraian diatas, penelitian ini bertujuan untuk: 1)menganalisis tingkat ketimpangan pendapatan antar kecamatan; 2)menganalisis tingkat kemajuan perekonomian; 3)menganalisis faktorfaktor yang mempengaruhi pencapaian IPM; 4)merumuskan strategi alokasi anggaran kesehatan dan pendidikan untuk mengurangi ketimpangan pembangunan manusia di Kota Depok.

\section{METODE PENELITIAN}

\section{Lokasi, Waktu dan Ruang Lingkup Penelitian}

Lokasi penelitian di Pemerintah Kota Depok, dengan pertimbangan Kota Depok meraih IPM tertinggi namun secara kewilayahan menunjukkan adanya ketimpangan IPM antar kecamatan dan terjadi kesenjangan gender. Pelaksanaan penelitian dilakukan selama empat bulan mulai bulan Februari sampai dengan bulan Mei 2016. Data sekunder IPM kecamatan masih menggunakan IPM metode lama dalam penelitian ini. Manajemen pengelolaan SMA/K berada di Pemerintah Provinsi sesuai UU No 23 Tahun 2014, namun baru efektif berlaku pada tahun ajaran 2017-2018, dimasukkannya SMA/K dalam perhitungan regresi untuk melihat pengaruhnya terhadap IPM selama periode 2012-2014.

Jenis, Pengumpulan, Pengolahan dan Analisis Data

Data sekunder diperoleh dari instansi terkait yaitu BPS, Dinas Kesehatan, Dinas Pendidikan, Badan Pemberdayaan Masyarakat dan Keluarga, Bappeda, Dinas Pendapatan dan Dinas Penerimaan dan Pengelolaan Keuangan dan Aset Daerah dan Kementerian Pemberdayaan Perempuan dan Anak. Data set yang digunakan dalam analisis regresi mencakup 11 kecamatan yang ada di wilayah Kota Depok tahun 2012-2014. Data primer diperoleh melalui wawancara, dengan menggunakan kuesioner. Pengambilan sampel dilakukan secara purposive sampling terhadap enam responden kunci yang dianggap memiliki kemampuan dan memahami permasalahan.

Tehnik pengolahan dan analisis data dalam penelitian ini yaitu:

1. Indeks Williamson untuk menganalisis tingkat ketimpangan pendapatan antar kecamatan (Tambunan 2003).

2. Tipologi Klassen untuk mengetahui tingkat kemajuan perekonomian dan tingkat pencapaian IPM masing- 
masing kecamatan serta bagaimana kecenderungannya (Kuncoro 2004).

3. Regresi Data Panel untuk menganalisis faktor-faktor yang mempengaruhi pencapaian IPM di Kota Depok (Gujarati 2005), dengan persamaan:

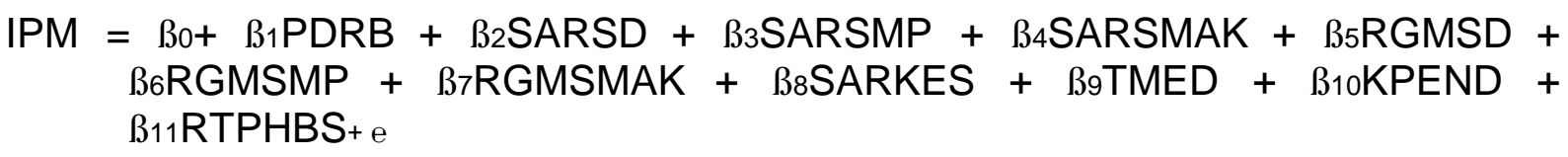

$\begin{array}{lll}\text { IPM } & = & \text { IPM Kecamatan } \\ \text { PDRB } & = & \text { PDRB per kapita } \\ \text { SARSD } & = & \text { Jumlah Sarana Pendidikan Sekolah Dasar } \\ \text { SARSMAK } & = & \text { Jumlah Sarana Pendidikan Sekolah Menengah Atas } \\ \text { RGMSD } & = & \text { Rasio Guru terhadap murid pada tingkat Sekolah Dasar } \\ \text { RGMSMAK } & = & \text { Rasio Guru terhadap murid pada tingkat Sekolah Menengah Atas } \\ \text { SARKES } & = & \text { Jumlah sarana kesehatan } \\ \text { TMED } & = & \text { Jumlah tenaga medis } \\ \text { KPEND } & = & \text { Kepadatan penduduk } \\ \text { RTPHBS } & = & \text { Persentase rumah tangga berperilaku hidup bersih dan sehat }\end{array}$

\section{HASIL DAN PEMBAHASAN}

\section{Perkembangan Tingkat Ketimpangan Pendapatan}

Nilai Indeks Williamson (IW) berkisar antara nol dan satu yang digambarkan dalam persamaan probabilitas: $0<\mathrm{IW}<1$. Nilai IW yang semakin mendekati nol menunjukkan bahwa distribusi pendapatan relatif lebih merata, sementara nilai IW yang semakin mendekati 1 menunjukkan adanya ketimpangan pendapatan pada wilayah yang dianalisis. Analisis 11 kecamatan selama periode 2012-2014, hasil perhitungan IW berada pada tingkat kesenjangan tinggi diatas 0.50 dan berfluktuasi (Gambar 1). Meningkatnya kesenjangan kecamatan pada tahun 2013 dipengaruhi oleh menurunnya laju pertumbuhan ekonomi Kota Depok secara keseluruhan.

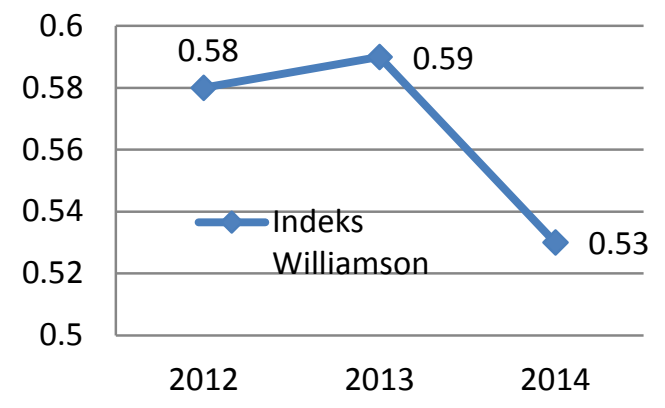

Sumber: BPS (data diolah kembali)

Gambar 1. Perkembangan IW Kota Depok
Tahun 2012-2014

Tahun 2010 sebagai masa awal pemekaran kecamatan, Kota Depok mengalami pertumbuhan ekonomi sebesar 6,36 persen. Selama periode 2010-2012 ekonomi Kota Depok mengalami pertumbuhan positif yaitu terjadi peningkatan menjadi sebesar 6,58 persen pada tahun 2011 dan meningkat kembali menjadi 7,15 persen pada tahun 2012. Pada tahun 2013 ekonomi Kota Depok sedikit mengalami perlambatan seiring dengan melambatnya pertumbuhan ekonomi nasional dan Jawa Barat. Hal ini mengindikasikan bahwa pertumbuhan ekonomi Kota Depok dipengaruhi oleh perkembangan ekonomi wilayah sekitarnya seperti Jakarta, Bogor, Tangerang dan Bekasi sebagai daerah pendukung. Meskipun demikian pertumbuhan ekonomi Kota Depok lebih tinggi daripada Jawa Barat, menunjukkan bahwa ekonomi Kota Depok tumbuh lebih cepat daripada ekonomi Provinsi Jawa Barat (Gambar 2).

Penurunan laju pertumbuhan ekonomi Kota Depok tahun 2013, dapat dilihat dari penurunan PDRB kecamatan. Meskipun secara umum PDRB Kota Depok dan rata-rata PDRB kecamatan mengalami peningkatan di tahun 2013, namun 7 dari 11 kecamatan yang ada di Kota Depok mengalami penurunan PDRB 
sejalan dengan kondisi perekonomian nasional yang melambat. Hanya 4 kecamatan yang memiliki pertumbuhan PDRB positif yaitu Kecamatan Cipayung, Kecamatan Cilodong, Kecamatan Cimanggis dan Kecamatan Beji. Sektor yang memberikan kontribusi besar pada peningkatan LPE Kota Depok pada tahun 2013 adalah sektor sekunder yaitu industri pengolahan, listrik dan bangunan yang merupakan dominasi kecamatan Cipayung dan Cilodong.

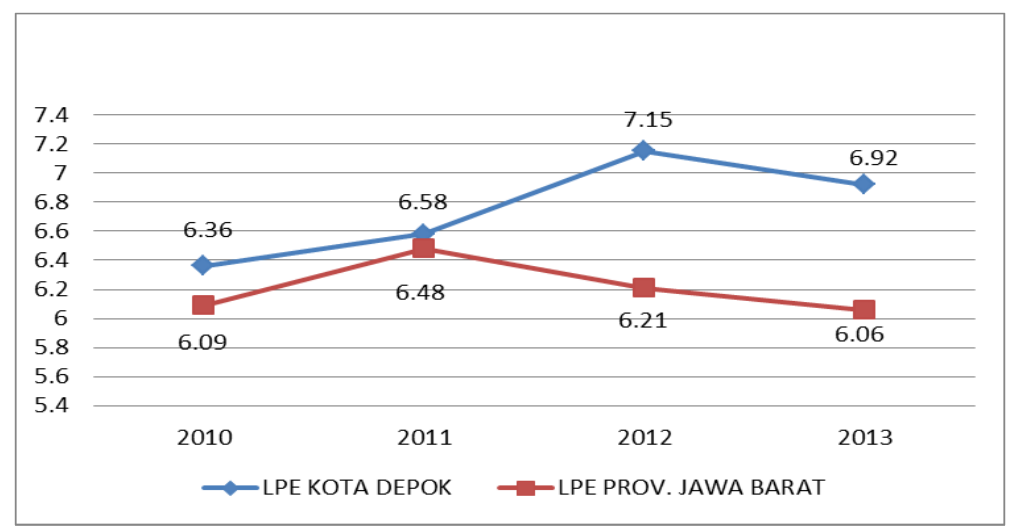

Sumber: PDRB Kota Depok 2013

Gambar 2. Laju Pertumbuhan Ekonomi Kota Depok Tahun 2010-2013

Laju pertumbuhan ekonomi Kota Depok kembali mengalami peningkatan dari 6,92 pada tahun 2013 menjadi 7,09 pada tahun 2014, dapat dilihat dari peningkatan PDRB kecamatan. Berbeda dengan tahun 2013, seluruh kecamatan mengalami peningkatan PDRB seiring dengan peningkatan PDRB Kota Depok dan rata-rata PDRB kecamatan di tahun 2014, yang dipengaruhi oleh pesatnya pertumbuhan investasi di bidang properti dan meningkatnya peran industri kreatif oleh intelektual individu masyarakat kaum muda di Kota Depok.

Tingkat kesenjangan pendapatan antar kecamatan dipengaruhi oleh PDRB perkapita kecamatan. Sebanyak empat kecamatan memiliki PDRB yang sangat tinggi melebihi kecamatan lainnya, menjadikan daerah tersebut sebagai daerah kantong dan ditempatkan sebagai data pencilan (Tadjoeddin et al. 2001).. Keempat kecamatan tersebut (Kecamatan Cilodong, Kecamatan Cimanggis, Kecamatan Tapos dan Kecamatan Beji) menguasai lebih dari 60 persen dari total PDRB Kota Depok dengan kecenderungan yang semakin meningkat. Pada tahun 2012 keempat kecamatan tersebut menguasai
$61,58 \%$ meningkat menjadi $61,72 \%$ pada tahun 2013 dan 61,89 pada tahun 2014.

Tadjoeddin et al. (2001) mengeluarkan daerah tersebut dari analisis, untuk menganalisis keberadaan dan peran dari out layers terhadap pola ketimpangan regional, sebagaimana dilakukan (Alam 2006) dan (Evianto 2010) dalam penelitiannya. Hasil analisis menunjukkan nilai IW konstan sebesar 0.24 sepanjang periode pengamatan (Gambar 3). Tingkat kesenjangan pendapatan antar kecamatan di Kota Depok tanpa keempat kecamatan tersebut berada pada tingkat kesenjangan rendah.

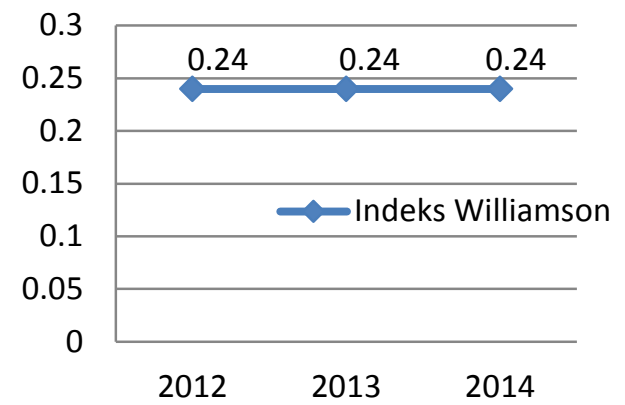

Sumber: BPS (data diolah kembali)

Gambar 3. Perkembangan IW Tanpa Cilodong, Cimanggis, Tapos dan Beji 
Hasil pengujian menggunakan analisis IW dapat disimpulkan bahwa:

1. Tingkat kesenjangan pendapatan antar kecamatan di wilayah Kota Depok berfluktuasi pada periode 2012-2014, namun bila dilakukan perbandingan antara awal dan akhir periode pengamatan, terjadi penurunan kesenjangan sejalan dengan pertumbuhan ekonomi yang semakin meningkat.

2. Pertumbuhan ekonomi mempengaruhi tingkat kesenjangan pendapatan antar kecamatan. Perlambatan ekonomi berdampak pada meningkatnya kesenjangan pendapatan antar kecamatan, sedangkan pertumbuhan ekonomi yang positif akan mengurangi tingkat kesenjangan antar kecamatan.

3. Adanya kecamatan yang memiliki PDRB perkapita sangat tinggi mempengaruhi tingkat kesenjangan pendapatan antar kecamatan. Semakin tinggi perbedaan PDRB perkapita maka kesenjangan antar kecamatan semakin meningkat, sebaliknya semakin rendah perbedaan PDRB perkapita maka kesenjangan antar kecamatan cenderung merata.
4.

\section{Tingkat Kemajuan Perekonomian dan Tingkat Pencapaian IPM}

Tipologi Klassen mengelompokkan kecamatan menjadi empat kuadran (Kuncoro 2004) seperti yang digunakan oleh (Alam 2006) dan (Evianto 2010) dalam penelitiannya. Hasil analisis menunjukkan bahwa masing-masing kecamatan memiliki karakteristik kemajuan atau tingkat kesejahteraan yang berbeda-beda dilihat dari PDRB perkapita dan laju pertumbuhan ekonomi, yaitu: 1) Kecamatan yang relatif stabil dalam tipologi yang sama meliputi kecamatan yang maju dan tumbuh cepat (kuadran I): Kecamatan Cilodong, Kecamatan Cimanggis dan Kecamatan Beji. Kecamatan yang relatif tertinggal (kuadran IV): Kecamatan Bojongsari, Kecamatan Pancoran Mas, Kecamatan Sukmajaya, Kecamatan Limodan kecamatan Cinere; 2) Kecamatan yang menunjukkan adanya kemajuan ekonomi: Kecamatan Tapos dan Kecamatan Sawangan; dan 3) Kecamatan yang mengalami kemunduran atau penurunan kesejahteraan: Kecamatan Cipayung (Gambar 4).

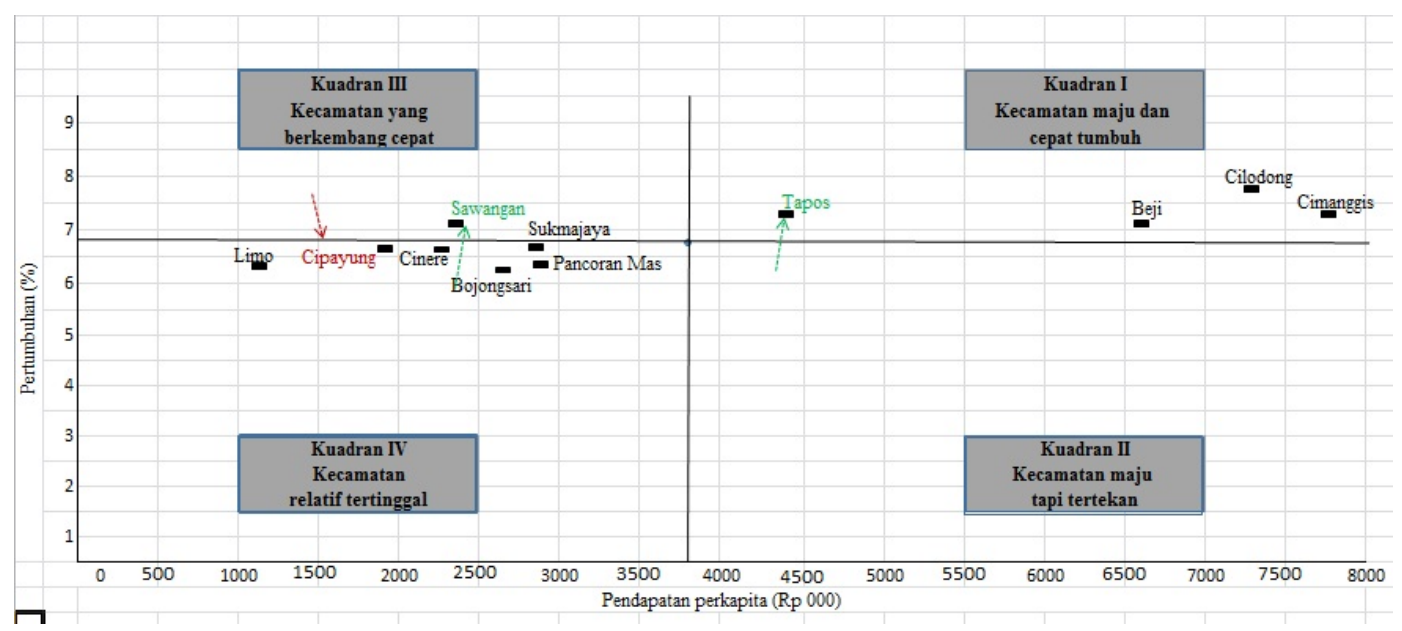

Sumber: BPS (data diolah kembali)

Gambar 4. Tingkat Kemajuan Kecamatan Menurut Tipologi Klassen Tahun 2014

Pengelompokan kecamatan ke dalam tipologi daerah, membagi daerah berdasarkan dua indikator utama yaitu IPM dan PDRB perkapita (Kuncoro 2004).
Hasilnya seluruh kecamatan berada pada tipologi yang sama selama periode pengamatan yaitu: 1) Kecamatan maju dan cepat tumbuh (kuadran I): Kecamatan 
Cimanggis dan Kecamatan Beji; 2) Kecamatan maju tapi tertekan (kuadran II): Kecamatan Cilodong dan Kecamatan Tapos; 3) Kecamatan yang berkembang cepat (kuadran III): Kecamatan Pancoran Mas, Kecamatan Sukmajaya dan Kecamatan Cinere; dan 4) Kecamatan yang relative tertinggal (kuadran IV): Kecamatan Sawangan, Kecamatan Bojongsari dan Kecamatan Limo. Hal ini menunjukkan tingkat kesenjangan cenderung tetap dan belum menunjukkan kearah perbaikan (Gambar 5).

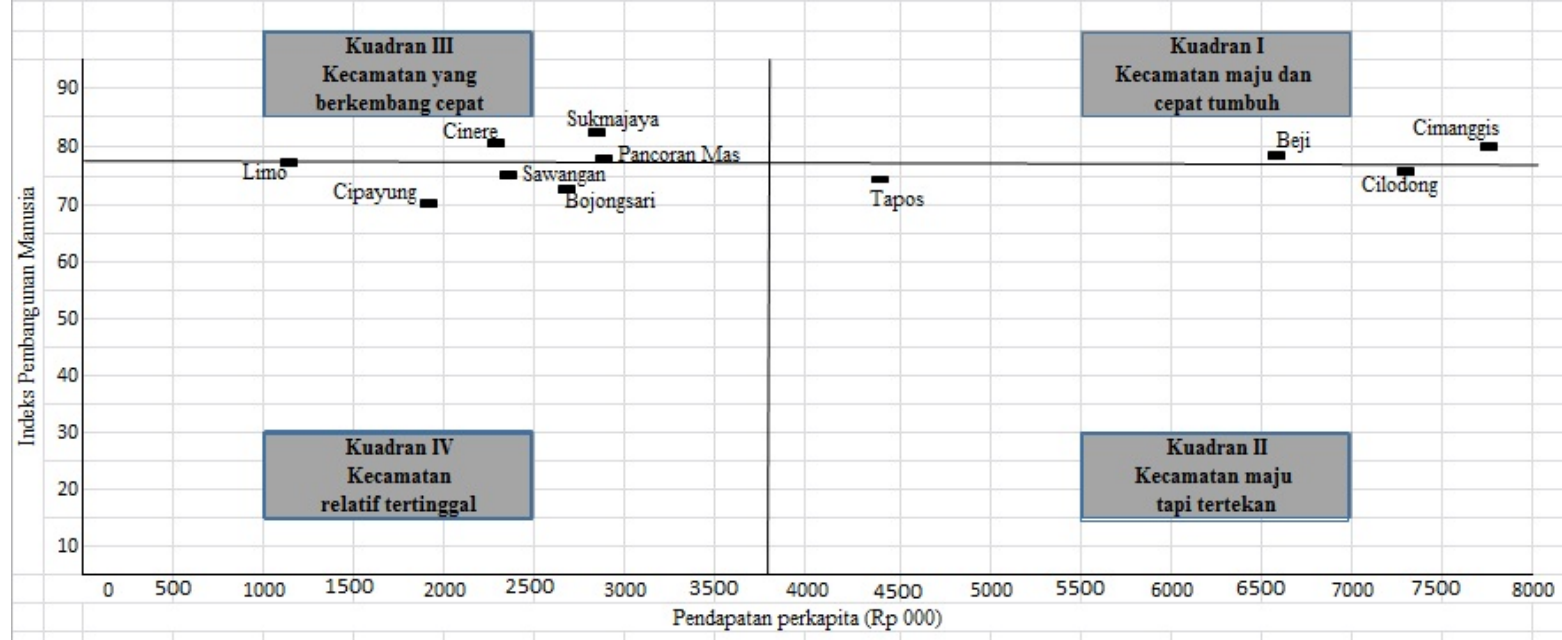

Sumber: BPS (data diolah kembali)

Gambar 5. Tipologi Daerah berdasarkan IPM dan PDRB perkapita Tahun 2012-2014

Berdasarkan pengujian baik dengan menggunakan tipologi Klassen dengan indikator LPE dan PDRB perkapita maupun tipologi daerah dengan indikator IPM dan PDRB perkapita menunjukkan hasil yang hampir sama, yaitu membagi kecamatan ke dalam dua bagian yaitu empat kecamatan dan tujuh kecamatan lainnya. Hasil perhitungan IW menunjukkan keempat kecamatan mempengaruhi pola ketimpangan wilayah, dimana tingkat kesenjangan kecamatan tanpa keempat kecamatan tersebut menjadi lebih rendah dan konstan.

\section{Keterkaitan antara Tingkat Kesenjangan Pendapatan dan Tingkat Kemajuan Kecamatan dengan Capaian IPM}

Analisis IW menghasilkan tingkat kesenjangan pendapatan antar kecamatan di Kota Depok adalah lebih besar dari 0,5 atau dapat dikatakan terdapat tingkat kesenjangan yang tinggi. Hasil analisis tipologi Klassen menunjukkan bahwa kecamatan di Kota Depok mengalami tingkat kemajuan yang beragam, sementara penggolongan kedalam tipologi daerah menunjukkan bahwa perkembangan kecamatan cenderung dalam tipologi yang sama selama periode pengamatan.

Capaian IPM suatu wilayah menggambarkan pencapaian pembangunan manusia pada suatu wilayah diukur dari aspek pendidikan, kesehatan dan daya beli. IPM menjadi alternatif indikator kesejahteraan masyarakat selain indikator pertumbuhan ekonomi yang lazim digunakan dalam mengukur kinerja perekonomian. Pemakaian indikator laju pertumbuhan ekonomi atau PDRB perkapita sering menyesatkan karena tingginya pertumbuhan ekonomi tidak selalu mampu mengatasi permasalahan yang ada seperti pengangguran dan kemiskinan.

Kecepatan perkembangan IPM dalam kurun waktu tertentu dihitung dengan menggunakan reduksi shortfall 
pertahun, yaitu perbandingan antara capaian yang telah ditempuh dengan capaian yang harus ditempuh untuk mencapai titik ideal IPM=100. Semakin besar reduksi shortfall pertahun menunjukkan semakin cepat pula kemajuan yang dicapai wilayah tersebut dalam periode pengamatan. Pada periode 2013-2014 sebagian besar kecamatan mengalami perkembangan IPM kategori cepat. Kecamatan yang mengalami peningkatan perkembangan IPM adalah Kecamatan Sawangan dan Kecamatan Cimanggis, sedangkan kecamatan yang mengalami perlambatan perkembangan IPM adalah Kecamatan Pancoran Mas, Kecamatan Tapos dan Kecamatan Beji.

Hasil analisis tingkat kemajuan kecamatan dengan menggunakan tipologi Klassen dan tipologi daerah dikaitkan dengan pencapaian IPM menunjukkan bahwa baik kelompok kecamatan maju dan cepat tumbuh maupun kecamatan yang relative tertinggal sebagian memiliki capaian IPM diatas rata-rata capaian IPM kecamatan dan sebagian lainnya dibawah rata-rata capaian IPM kecamatan. Tidak satupun kelompok kecamatan yang maju dan cepat tumbuh memiliki capaian IPM diatas capaian IPM Kota Depok.

\begin{tabular}{|c|c|c|c|}
\hline \multicolumn{2}{|c|}{$\begin{array}{l}\text { Tingkat kemajuan } \\
\text { perekonomian kecamatan }\end{array}$} & \multirow{2}{*}{$\begin{array}{c}\text { Rata-rata } \\
\text { IPM Kecamatan } \\
77.28 \\
<\end{array}$} & \multirow{2}{*}{$\begin{array}{c}\text { IPM } \\
\text { Kota Depok } \\
\text { 8o.58 } \\
<\end{array}$} \\
\hline \multirow{4}{*}{$\begin{array}{l}\text { I. Kec. maju } \\
\text { \& cepat } \\
\text { tumbuh }\end{array}$} & Cilodong & & \\
\hline & Cimanggis & $>$ & $<$ \\
\hline & Beji & $>$ & $<$ \\
\hline & Tapos & $<$ & $<$ \\
\hline \multirow{2}{*}{$\begin{array}{c}\text { III. Kec. } \\
\text { Berkembang } \\
\text { cepat }\end{array}$} & Sawangan & $<$ & $<$ \\
\hline & & & \\
\hline \multirow{6}{*}{$\begin{array}{l}\text { IV. Kec. } \\
\text { relatif } \\
\text { tertinggal }\end{array}$} & Bojongsari & $<$ & $<$ \\
\hline & Pancoran Mas & $>$ & $<$ \\
\hline & Cipayung & $<$ & $<$ \\
\hline & Sukmajaya & $>$ & $>$ \\
\hline & Limo & $<$ & $<$ \\
\hline & Cinere & $>$ & $=$ \\
\hline
\end{tabular}

Gambar 6. Keterkaitan antara tingkat kemajuan perekonomian dengan IPM
Menariknya adalah Kecamatan Sukmajaya sebagai kecamatan yang relatif tertinggal dilihat dari laju pertumbuhan ekonomi dan kemajuan PDRB justru menjadi satu-satunya kecamatan yang memiliki capaian IPM diatas capaian IPM Kota Depok (Gambar 6). Hal ini menunjukkan bahwa pertumbuhan ekonomi yang tinggi belum tentu menghasilkan capaian pembangunan manusia yang tinggi pula. Tingginya pertumbuhan ekonomi belum sepenuhnya meningkatkan kesejahteraan masyarakat melalui distribusi pendapatan yang lebih merata dan meningkatnya kualitas pembangunan manusia.

\section{Perkembangan Indeks Pembangunan Manusia (IPM)}

Capaian IPM Kota Depok periode 2010-2014 menunjukkan tren yang terus meningkat demikian pula capaian IPM kecamatan (Tabel 1). Hal ini menunjukkan bahwa pembangunan manusia di Kota Depok terus mengalami peningkatan. Kecamatan dengan nilai IPM tertinggi dan diatas IPM Kota Depok adalah Kecamatan Sukmajaya disusul kecamatan Cinere. Sedangkan kecamatan dengan nilai IPM terendah adalah kecamatan Cipayung. Hal ini disebabkan komponen penyusun IPM yaitu Angka Harapan Hidup (AHH), Angka Melek Huruf (AMH), Rata-rata Lama Sekolah (RLS) dan Paritas daya beli (PPP) kecamatan Cipayung terendah dibanding kecamatan lainnya (Tabel 2). 
Tabel 1. IPM Kecamatan dan Kota Depok periode Tahun 2010-2014

\begin{tabular}{rllllll}
\hline No & \multicolumn{1}{c}{ Kecamatan } & 2010 & 2011 & 2012 & 2013 & $\left.2014^{*}\right)$ \\
\hline 1 & Sawangan & 74.86 & 75.10 & 75.34 & 75.55 & 75.94 \\
2 & Bojongsari & 72.75 & 73.33 & 73.87 & 74.47 & 74.99 \\
3 & Pancoran Mas & 75.75 & 76.46 & 76.84 & 77.36 & 77.68 \\
4 & Cipayung & 67.38 & 68.32 & 68.99 & 69.95 & 70.74 \\
5 & Sukmajaya & 79.85 & 80.40 & 80.81 & 81.23 & 81.94 \\
6 & Cilodong & 75.00 & 75.44 & 75.84 & 76.27 & 77.09 \\
7 & Cimanggis & 78.14 & 78.96 & 79.42 & 79.77 & 80.51 \\
8 & Tapos & 72.92 & 73.34 & 73.71 & 74.13 & 74.49 \\
9 & Beji & 76.88 & 77.54 & 77.99 & 78.55 & 78.87 \\
10 & Limo & 75.13 & 75.63 & 76.12 & 76.63 & 77.28 \\
11 & Cinere & 78.72 & 79.25 & 79.67 & 80.20 & 80.58 \\
\hline \multicolumn{2}{l}{ Kota Depok } & 79.09 & 79.49 & 79.71 & 80.14 & 80.58 \\
\hline
\end{tabular}

Sumber: BPS

Secara umum Kota Depok sudah mencapai tingkat harapan hidup yang tinggi, yaitu sebesar 73,75. Artinya warga Kota Depok yang lahir di tahun 2014 mempunyai harapan hidup sampai dengan hampir 74 tahun. Hal ini menunjukkan sarana dan prasarana kesehatan yang ada di Kota Depok sudah cukup memadai.
Kecamatan dengan AHH tertinggi adalah kecamatan Sukmajaya sebesar 74,91 dan terendah adalah kecamatan Cipayung sebesar 67,95. Selain kecamatan Cipayung, kecamatan yang mempunyai AHH kurang dari 70,00 adalah kecamatan Sawangan, Bojongsari, Pancoran Mas, Tapos, Beji, Limo.

Tabel 2. IPM Kecamatan di Kota Depok Tahun 2014

\begin{tabular}{lcccc}
\hline \multicolumn{1}{c}{ Kecamatan } & AHH & AMH & RLS & PPP \\
\hline Sawangan & 68,21 & 99,18 & 10,63 & 645,81 \\
Bojongsari & 69,16 & 97,44 & 10,21 & 635,83 \\
Pancoran Mas & 68,63 & 99,61 & 11,44 & 656,44 \\
Cipayung & 67,95 & 97,77 & 9,46 & 595,55 \\
Sukmajaya & 74,91 & 99,59 & 12,37 & 657,52 \\
Cilodong & 73,89 & 99,03 & 10,92 & 617,57 \\
Cimanggis & 74,08 & 99,44 & 11,25 & 656,09 \\
Tapos & 69,65 & 98,79 & 10,77 & 616,37 \\
Beji & 69,60 & 99,81 & 12,04 & 658,49 \\
Limo & 69,53 & 99,23 & 10,06 & 659,01 \\
Cinere & 72,03 & 99,07 & 11,89 & 666,78 \\
Kota Depok & 73,75 & 99,07 & 11,16 & 661,30 \\
\hline
\end{tabular}

Sumber: BPS

AMH tertinggi adalah kecamatan Beji sebesar 99,81 persen, disusul Sukmajaya dan Pancoran Mas. Hal ini menggambarkan bahwa masyarakat kota
Depok yang berumur 15 tahun keatas memiliki AMH rata-rata sudah diatas 95 persen. Kecamatan yang AMH masih dibawah 99,00 persen adalah kecamatan 
Cipayung dan Bojongsari, menunjukkan bahwa kedua kecamatan tersebut penduduk yang belum bisa baca tulis diatas 5\% disebabkan putus sekolah atau tidak pernah mengenyam pendidikan.

RLS tertinggi adalah kecamatan Beji mencapai 12,04 tahun artinya rata-rata sudah lulus SLTA. selanjutnya Sukmajaya dan Cinere Pancoran Mas diatas 11 tahun artinya lama sekolah penduduk yang berumur 15 tahun keatas sampai dengan kelas 11 atau kelas 2 SLTA, terendah Limo dan Cipayung. Tidak sampai 10 tahun atau sampai dengan kelas 3SLTP. Secara umum angka rata-rata lama sekolah penduduk berumur 15 tahun keatas di kota Depok adalah sampai dengan kelas 2 SLTA.Hal ini menunjukkan jumlah Sekolah Menengah Atas Negeri di kota Depok tidak sebanding dengan banyaknya murid yang harus sekolah sementara sekolah di SLTA swasta memerlukan dana yang cukup bahkan mungkin mahal sehingga tidak terjangkau oleh masyarakat yang berpenghasilan kecil.

PPP Kota Depok sebesar 661.30 ribu rupiah, artinya bahwa penduduk Kota Depok pada tahun 2014 mengeluarkan uang untuk konsumsi sebesar 661.30 ribu rupiah setiap orang selama satu tahun yang telah disesuaikan. Daya beli masyarakat Kota Depok lebih tinggi daripada nilai rata-rata Provinsi Jawa Barat sebesar 644.36 ribu rupiah, hal ini menunjukkan daya saing Kota Depok sebagai potensi pasar yang cukup besar terhadap wilayah lainnya di Provinsi Jawa Barat.

Kecamatan Cinere adalah kecamatan dengan PPP paling besar yaitu 666.78 ribu rupiah dan yang terkecil sebesar 595.33 ribu rupiah di kecamatan Cipayung. Kecamatan Cinere dengan PPP tertinggi tidak serta merta mencerminkan kesejahteraan keseluruhan penduduk karena ketimpangan pendapatan antar penduduk belum bisa dilihat dengan angka PPP. Diperlukan alat pengukuran lain untuk melihat ketimpangan pendapatannya misalnya dengan menghitung Gini Rationya.

\section{Perkembangan Indeks Pembangunan Gender (IPG)}

IPG merupakan salah satu ukuran pencapaian pembangunan gender yang merupakan turunan dari IPM. Melalui angka IPG, kesenjangan pembangunan manusia antara laki-laki dan perempuan mampu dijelaskan dengan melihat rasio antara IPM perempuan dengan laki-laki. Berdasar Tabel 3 rasio IPG mengalami peningkatan, namun tidak secepat kenaikan IPM.

Tabel 3. IPM, IPM Laki-Laki, IPM Perempuan dan IPG 2010-2013

\begin{tabular}{rcccc}
\hline Tahun & IPM & IPM Laki-laki & IPM Perempuan & IPG \\
\hline 2010 & 79.09 & 63.55 & 45.17 & 71.94 \\
2011 & 79.36 & 63.68 & 45.24 & 72.68 \\
2012 & 79.91 & 63.79 & 45.55 & 72.94 \\
2013 & 80.14 & 63.95 & 46.00 & 73.63 \\
\hline
\end{tabular}

Sumber: Laporan Pembangunan Manusia Berbasis Gender (diolah)

Komponen pembentuk IPG sama dengan komponen pembentuk IPM, yaitu AHH, AMH, RLS dan PPP yang disajikan menurut jenis kelamin. AHH perempuan di Kota Depok lebih tinggi dari laki-laki, meskipun keduanya menunjukkan tren peningkatan pada periode 2010-2013 (Gambar 7).

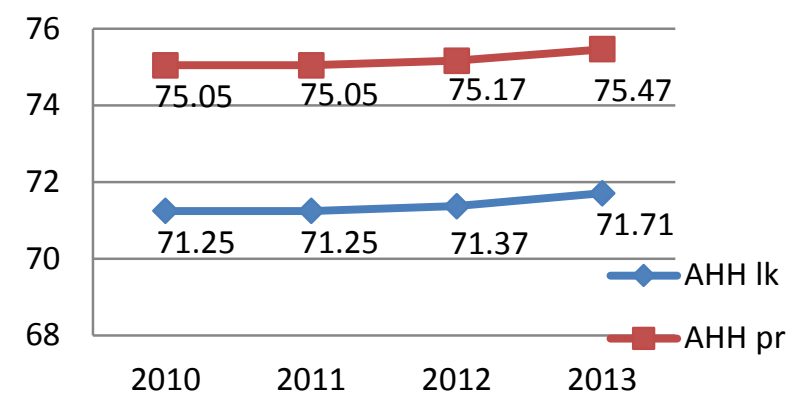

Sumber: Pembangunan Manusia Berbasis Gender 2011-2014

Gambar 7. Perkembangan AHH Menurut Jenis Kelamin Tahun 2010-2013

Penduduk perempuan di Kota Depok memiliki harapan hidup rata-rata sebesar 75 tahun sedangkan penduduk laki-laki memiliki harapan hidup sebesar 71 tahun. Secara umum terdapat perbedaan level capaian $\mathrm{AHH}$ antara perempuan dan 
laki-laki, dimana level AHH untuk penduduk laki-laki lebih rendah 4 tahun dibanding level $\mathrm{AHH}$ penduduk perempuan. Selain itu pola pergerakan AHH penduduk laki-laki dalam periode tersebut tidak cukup cepat untuk mempersempit kesenjangan dengan pencapaian $\mathrm{AHH}$ perempuan. Fenomena tersebut tidak hanya terjadi di Kota Depok, namun secara nasional AHH perempuan lebih tinggi dari laki-laki. Hal ini kemungkinan disebabkan faktor bawaan lahir dimana perempuan memiliki sepasang kromosom sehingga memiliki kemampuan lebih untuk bertahan hidup, sementara laki-laki hanya memiliki kromosom tunggal. Selain itu wanita diyakini lebih memperhatikan pola hidup sehat dan gaya hidup yang lebih teratur dibandingkan dengan laki-laki.

AMH dan RLS merepresentasikan dimensi pengetahuan baik dalam IPM maupun IPG. AMH menggambarkan persentase penduduk umur 15 tahun keatas yang mampu baca tulis, sedangkan RLS menggambarkan rata-rata jumlah tahun yang diperlukan untuk menempuh pendidikan formal pada semua jenjang pendidikan. AMH dipergunakan untuk melihat potensi intelektual penduduk lakilaki perempuan, sekaligus kontribusi yang dapat diberikan dalam pembangunan di Kota Depok (Gambar 8).

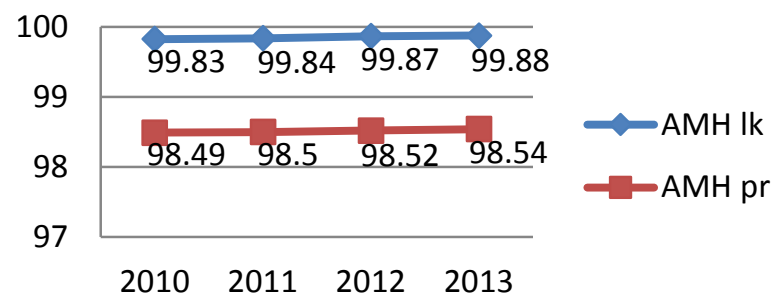

Sumber: Laporan Pembangunan Manusia Berbasis Gender 2014

Gambar 8. Perkembangan AMH Menurut Jenis Kelamin Tahun 2010-2013

Berdasarkan grafik diatas, secara umum menunjukkan bahwa $\mathrm{AMH}$ perempuan masih lebih rendah 80 dibandingkan dengan AMH laki-laki. Berbeda di tingkat nasional dimana laju pertumbuhan AMH perempuan sedikit lebih cepat dibandingkan AMH laki-laki, laju pertumbuhan $\mathrm{AMH}$ perempuan dan AMH laki-laki di Kota Depok memiliki laju peningkatan yang sama yaitu rata-rata sebesar 0.02 persen pada periode 20102013. Kenaikan AMH perempuan belum mampu mengurangi kesenjangan dengan AMH laki-laki, sehingga masih ada ketimpangan dalam hal baca dan tulis di Kota Depok. Hal tersebut kemungkinan disebabkan belum meratanya akses pendidikan dasar bagi perempuan terutama pada keluarga miskin. Kemungkinan lain disebabkan oleh ketidakmampuan baca dan tulis pada penduduk golongan tua usia 70 tahun keatas, dimana perempuan lebih banyak jumlahnya daripada laki-laki.

Sama halnya dengan AMH, capaian RLS laki-laki selalu diatas capaian RLS perempuan, dengan rata-rata perbedaan kurang dari 1,5 tahun. Pada periode 2010-2013 pola peningkatan RLS baik laki-laki maupun perempuan relatif sama (Gambar 9). Rata-rata capaian RLS laki-laki sebesar 11,90 tahun atau setara dengan kelas 2 SMA, sedangkan rata-rata capaian RLS perempuan sebesar 10,54 tahun atau setara dengan kelas 1 SMA.

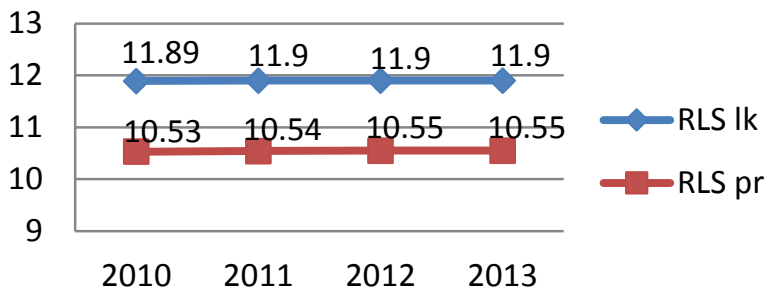

Sumber: Laporan Pembangunan Manusia Berbasis Gender 2014

Gambar 9. Perkembangan RLS Menurut Jenis Kelamin Tahun 2010-2013

Sumbangan pendapatan menurut jenis kelamin merupakan kontribusi dibidang ketenagakerjaan. baik oleh perempuan maupun laki-laki. Secara umum sumbangan pendapatan laki-laki lebih besar daripada perempuan pada periode 2010-2013 (Gambar 10). Rata-rata sumbangan pendapatan laki-laki sebesar 68,93 persen sedangkan 31,07 persen 
sisanya perempuan. SP laki-laki menunjukkan tren penurunan, sebaliknya SP perempuan menunjukkan tren peningkatan. Hal ini kemungkinan disebabkan meningkatnya partisipasi perempuan dalam ketenagakerjaan akan meningkatkan proporsi sumbangan pendapatan perempuan sehingga mempersempit kesenjangan antara SP perempuan dengan SP laki-laki.

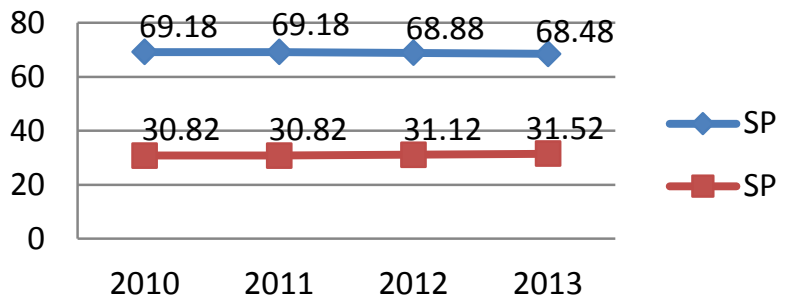

Sumber: Laporan Pembangunan Manusia Berbasis Gender 2011-2014

Gambar 10. Perkembangan SP Menurut Jenis Kelamin Tahun 2010-2013

\section{Analisis Regresi terhadap Faktor-faktor yang Mempengaruhi Pencapaian IPM}

Penentuan faktor-faktor yang mempengaruhi IPM di Kota Depok dianalisis menggunakan metode regresi data panel, dengan alat pengolahan data Eviews 7. Pada model regresi ini terdapat sepuluh variabel regresi, yaitu IPM sebagai variabel terikat dan sembilan variabel bebas yang diduga mempengaruhi variabel terikat. Kesembilan variabel bebas tersebut adalah PDRB perkapita, Jumlah Sekolah Dasar (SD), Jumlah Sekolah Menengah Atas (SMA/K), Rasio Guru terhadap Murid tingkat SD, Rasio Guru terhadap Murid tingkat SMA/K, Jumlah Puskesmas, Jumlah Tenaga Kesehatan, Kepadatan Penduduk dan Persentase Rumah Tangga Berperilaku Hidup Bersih dan Sehat.

Model regresi data panel yaitu fixed effect dan random effect akan diuji dengan uji chow dan uji hausman untuk dipilih model yang terbaik. Tabel 4 menunjukkan pengujian menggunakan chowtest/likehood ratio test yaitu Ho: model mengikuti pool Hl: model mengikuti fixed. Output Eviews menunjukkan baik $\mathrm{F}$ test maupun chi-square signifikan sehingga Ho ditolak, maka model FEM lebih baik dibanding PLS. Demikian pula hasil pengujian Hausman test yaitu Ho: random effect dan H1: fixed effect. Output Eviews terlihat bahwa p-value signifikan sehingga Ho ditolak, maka model FEM lebih baik dibanding PLS (Juanda dan Junaidi 2012).

Tabel 4. Hasil Pemilihan Model

Chow-test/likehood ratio test

\begin{tabular}{lcrr}
\hline Effect Test & Statistic & d.f & Prob \\
\hline Cross section F & 569.980847 & $(10.13)$ & 0.0000 \\
Cross section Chi-Square & 200.822050 & 10 & 0.0000 \\
\hline
\end{tabular}

Hausman test

\begin{tabular}{lccr}
\hline Test Summary & Chi-Sq Statistic & Chi-Sq d.f & \multicolumn{2}{c}{ Prob } \\
\hline Cross section random & 192.063601 & 9 & 0.0000
\end{tabular}

Berdasarkan Tabel 4 maka pemilihan model terbaik untuk mengestimasi pengaruh sembilan variabel bebas terhadap variabel terikat IPM adalah model fixed effect. Hasil analisis regresi data panel model persamaan dengan variabel terikat IPM dijelaskan dalam Tabel 5. Selanjutnya dilakukan uji-uji untuk memastikan parameter persamaan regresi yang terbentuk merupakan estimator terbaik. Uji signifikansi $F$ untuk mengetahui apakah semua variabel bebas mempengaruhi variabel terikat secara bersama-sama (Gujarati 2005). Berdasarkan hasil estimasi pada Tabel 3 dapat disimpulkan bahwa nilai $\mathrm{F}$ statistik signifikan pada taraf nyata $\alpha=1$ persen, artinya semua variabel bebas mampu 
menjelaskan variabel terikat secara bersama-sama.

Uji signifikansi-t atau uji koefisien regresi secara parsial digunakan untuk melihat apakah koefisien regresi variabel bebas dapat menjelaskan perubahan variabel terikat. (Gujarati 2005). Tabel 3 menunjukkan sarana pendidikan sekolah dasar, rasio guru murid sekolah dasar, rasio guru murid sekolah menengah atas dan kepadatan penduduk pada taraf nyata $\alpha$ $($ alfa $)=5 \%$ dan variabel PDRB pada taraf nyata $\alpha$ (alfa) $=10 \%$. Empat variabel lainnya yaitu sedangkan variabel sarana sekolah menengah atas, variabel sarana kesehatan, variabel jumlah tenaga kesehatan dan variabel rumah tangga berperilaku hidup bersih dan sehat tidak signifikan menjelaskan perubahan IPM.

Tabel 5. Hasil Analisis Regresi Model Terbaik

\begin{tabular}{lllll}
\hline Variable & \multicolumn{1}{c}{ Coefisient } & \multicolumn{1}{c}{ Std. Error } & \\
\hline PDRB & 1.165478 & $0.598771^{\mathrm{b}}$ & & \\
SARSD & 0.072063 & $0.023845^{\mathrm{a}}$ & & \\
SARSMAK & -0.027330 & 0.023515 & & \\
RGMSD & -0.013054 & $0.004971^{\mathrm{a}}$ & & \\
RGMSMAK & -0.020577 & $0.005698^{\mathrm{a}}$ & & $99.93 \%$ \\
SARKES & -0.156761 & 0.108390 & & 0.998251 \\
TKES & -0.000702 & 0.001565 & $\mathrm{R}^{2}$ & $962.0117^{\mathrm{a}}$ \\
KPEND & 0.491050 & $0.218307^{\mathrm{a}}$ & Adj. $\mathrm{R}^{2}$ & \\
RTPHBS & 0.000830 & 0.003655 & F stat & \\
C & 65.48222 & 2.017372 & DW Stat & 2.898711 \\
\hline${ }^{a}$ nyata pada taraf $\alpha=5 \%$ & & &
\end{tabular}

${ }^{\mathrm{b}}$ nyata pada taraf $\alpha=10 \%$

Uji koefisien determinasi yang disesuaikan (Adj. R²) dilakukan untuk menjelaskan berapa besar variabel bebas oleh variabel terikat. Penggunaan uji ini untuk mengatasi kelemahan $\mathrm{R}^{2}$ ketika terjadi penambahan variabel. Berdasarkan Tabel 3 persamaan regresi menunjukkan nilai Adj. $\mathrm{R}^{2}$ diatas 99 persen yaitu 99.83. Hal ini menunjukkan bahwa persamaan regresi yang dibangun dapat menjelaskan lebih dari 99 persen variasi dari perkembangan IPM.

Untuk mengetahui apakah persamaan yang dihhasilkan telah memenuhi asumsi BLUE (Best Linier Unbiased Estimator) dilakukan berbagai uji asumsi klasik meliputi: uji normalitas, uji multikolinearitas, uji autokorelasi dan uji heteroskedastisitas. Hasil uji asumsi klasik menyebutkan model telah bebas dari masalah normalitas, multikoleniaritas dan 82 heterokedastisitas. Uji asumsi klasik untuk mendeteksi otokorelasi yang menjadi penyakit bawaan pada data time series, yaitu dengan membandingkan nilai Durbin-Watson (DW stat) hasil regresi dengan angka dalam tabel Durbin-Watson. Dalam model ini, jumlah $(n=33)$ dan variabel bebas $(\mathrm{k}=9)$ dengan hasil perhitungan nilai DW tidak dapat diputuskan ada tidaknya otokorelasi, sehingga kemungkinan estimator hanya bersifat LUE, tidak lagi BLUE.

Secara umum hasil penelitian menunjukkan bahwa dari sembilan variabel yang diasumsikan berpengaruh terhadap variasi pencapaian IPM, ternyata hanya lima variabel yang berpengaruh signifikan yaitu sarana pendidikan sekolah dasar, rasio guru murid sekolah dasar, rasio guru murid sekolah menengah atas dan kepadatan penduduk pada taraf nyata $\alpha$ $($ alfa $)=5 \%$ dan variabel PDRB pada taraf nyata $\alpha$ (alfa) $=10 \%$ dengan tingkat kepercayaan $99.93 \%$ sedangkan $0.07 \%$ 
sisanya dipengaruhi oleh variabel-variabel lain diluar model.

Koefisien $\quad \mathrm{R}^{2} \quad$ sebesar $\quad 99.93 \%$ menunjukkan kecocokan model (goodness of fit). Model persamaan regresi dengan variabel bebas yaitu: PDRB, jumlah SD, jumlah $\mathrm{SMA} / \mathrm{K}$, rasio guru murid $\mathrm{SD}$, rasio guru murid SMA/K, jumlah puskesmas, jumlah tenaga kesehatan, kepadatan penduduk dan rumah tangga berperilaku hidup bersih dan sehat mampu menjelaskan pengaruhnya terhadap variabel terikat IPM sebesar 99.93\%, sedangkan $0.07 \%$ sisanya dijelaskan oleh variabel lain diluar model. Uji serempak pengaruh semua variabel independen terhadap variabel dependen, nilai F-stat 962.0117a menunjukkan adanya pengaruh yang signifikan. Nilai konstanta 65.48222 berarti bahwa jika tidak terdapat kenaikan nilai dari variabel-variabel bebas, maka IPM berada pada angka 65.48222.

Indikator kesehatan berupa variabel sarana kesehatan, variabel jumlah tenaga kesehatan dan variabel rumah tangga berperilaku hidup bersih dan sehat tidak signifikan menjelaskan perubahan IPM sejalan dengan hasil penelitian (Setyowati 2011) dan (Astri 2013), dimana pengeluaran pemerintah sektor kesehatan tidak berpengaruh terhadap IPM, sementara (Waluyo 2011) pengeluaran pemerintah sektor kesehatan berpengaruh negatif.

Variabel sarana sekolah menengah atas dan variabel sarana kesehatan tidak berpengaruh signifikan terhadap pencapaian IPM disebabkan pertambahan jumlah sarana sekolah menengah atas dan sarana kesehatan sangat lambat dan tidak sebanding dengan pertambahan jumlah penduduk yang sangat pesat, sehingga tidak mampu mempengaruhi peningkatan IPM. Jumlah tenaga medis tidak sebanding dengan jumlah penduduk dan kurangnya kesadaran rumah tangga berperilaku hidup bersih dan sehat, tidak mampu mempengaruhi peningkatan IPM.

Variabel yang signifikan dengan koefisien regresi bernilai negatif yaitu rasio guru murid sekolah dasar dan rasio guru murid sekolah menengah atas. Rasio guru murid yang tinggi yaitu perbandingan guru dengan jumlah murid yang diampu berada diatas rasio ideal, akan mengurangi daya tangkap murid sehingga mengurangi efektivitas kegiatan belajar mengajar, sedangkan rasio guru murid yang rendah dapat menyebabkan kegiatan belajar mengajar menjadi kurang efisien karena jumlah guru terlalu banyak.

Persamaan tersebut diketahui bahwa setiap kenaikan PDRB perkapita sebesar Rp 1 juta akan meningkatkan IPM sebesar 1.16. PDRB perkapita berpengaruh positif dan signifikan sejalan dengan hasil penelitian (Alam 2006) dan (Evianto 2010). Setiap kenaikan kepadatan penduduk sebesar 1000 jiwa per $\mathrm{km}^{2}$ akan meningkatkan IPM sebesar 0.49. Hal ini sejalan dengan hasil penelitian (Alam 2006) sedangkan (Evianto 2010) berpengaruh negatif. Setiap kenaikan sarana sekolah dasar sebesar satu akan meningkatkan IPM sebesar 0.07, setiap kenaikan/penurunan rasio guru murid SD akan mempengaruhi IPM sebesar 0.01, setiap kenaikan/penurunan rasio guru murid SMA/K akan mempengaruhi IPM sebesar 0.02 .

Karakteristik IPM kecamatan digambarkan dalam nilai intersepnya. Nilai intersep setiap kecamatan adalah kondisi awal antar daerah, dimana slope untuk setiap kecamatan tetap (Tabel 6). Hasil analisis menunjukkan perbedaan intersep antar kecamatan relatif mencolok yaitu berkisar antara -4.814162 sampai dengan 5.778151. Kesenjangan IPM antar kecamatan relatif tinggi. Nilai intersep tertinggi terdapat di Kecamatan Cinere sebesar 5.779151, sedangkan nilai intersep terendah terdapat di Kecamatan Cipayung sebesar -4.814162. Tingginya kesenjangan IPM berdasarkan variasi intersip antar kecamatan hasil analisis regresi sejalan dengan hasil analisis IW. 
Tabel 6. Variasi Konstanta antar Kecamatan

\begin{tabular}{clc}
\hline No & \multicolumn{1}{c}{ Kecamatan } & $\begin{array}{c}\text { Koefisien } \\
\text { Regresi }\end{array}$ \\
\hline 1 & Sawangan & 3.299065 \\
2 & Bojongsari & 1.337518 \\
3 & Pancoran Mas & -1.082857 \\
4 & Cipayung & -4.814162 \\
5 & Sukmajaya & 1.827853 \\
6 & Cilodong & -2.896717 \\
7 & Cimanggis & -3.732547 \\
8 & Tapos & -2.358949 \\
9 & Beji & -2.259761 \\
10 & Limo & 4.902407 \\
11 & Cinere & 5.779151 \\
\hline
\end{tabular}

\section{SIMPULAN DAN SARAN}

\section{Simpulan}

Tingkat kesenjangan pendapatan antar kecamatan di wilayah Kota Depok berfluktuasi pada periode 2012-2014 dan cenderung menurun sejalan dengan pertumbuhan ekonomi yang positif, tetapi adanya kecamatan yang memiliki PDRB perkapita sangat tinggi mempengaruhi pola ketimpangan wilayah.

Berdasarkan pengujian baik dengan menggunakan tipologi Klassen dengan indikator LPE dan PDRB perkapita maupun tipologi daerah dengan indikator IPM dan PDRB perkapita menunjukkan hasil yang hampir sama, yaitu membagi kecamatan ke dalam dua bagian yaitu empat kecamatan dan tujuh kecamatan lainnya. Tingginya pertumbuhan ekonomi belum sepenuhnya dapat meningkatkan kesejahteraan masyarakat melalui distribusi pendapatan yang lebih merata dan meningkatnya kualitas pembangunan manusia.

Hasil analisis deskriptif menunjukkan terdapat ketimpangan IPM dan kesenjangan gender. Hasil analisis regresi menunjukkan dari sembilan variabel yang diasumsikan berpengaruh terhadap variasi pencapaian IPM, ternyata hanya lima variabel yang signifikan 84 berpengaruh terhadap variabel IPM yaitu sarana pendidikan sekolah dasar, rasio guru murid sekolah dasar, rasio guru murid sekolah menengah atas dan kepadatan penduduk pada taraf nyata $\alpha$ (alfa) $=5 \%$ dan variabel PDRB pada taraf nyata $\alpha$ $($ alfa $)=10 \%$, dengan tingkat kepercayaan 99.93\%.

\section{Saran}

Perlunya disusun indikator yang mencerminkan kondisi riil daerah meliputi pertumbuhan ekonomi daerah, PDRB perkapita dan Indeks Pembangunan Manusia dan Indeks Pembangunan Gender. Indikator tersebut diharapkan dapat menjadi rujukan bagi Pemerintah Kota Depok untuk mempercepat pembangunan pada kecamatan-kecamatan yang relatif tertinggal, serta dapat menjadi acuan bagi investor memilih lokasi investasi.

Upaya mengurangi ketimpangan pembangunan manusia membutuhkan komitmen dan peran aktif Pemerintah Kota Depok dalam merencanakan kebijakan yang memprioritaskan alokasi anggaran belanja untuk program-program yang bersentuhan langsung dengan masyarakat dibidang kesehatan, pendidikan dan ekonomi, khususnya pada kecamatan yang capaian IPM nya rendah. Dukungan Pemerintah Pusat, peran serta masyarakat dan swasta dalam bentuk Public Private Partnership sangat diperlukan dalam mengatasi keterbatasan anggaran daerah.

Penelitian ini memiliki keterbatasan jumlah tahun pengamatan data sekunder yang digunakan dalam analisis, disarankan untuk penelitian selanjutnya dapat menambah jumlah tahun pengamatan dan menambah variabel bebas sehingga kesimpulan yang diamnil lebih tajam.

\section{DAFTAR PUSTAKA}

Alam J. 2006. Disparitas Pendapatan dan Faktor-faktor yang berpengaruh dalam Pencapaian Indeks Pembangunan Manusiadi Kabupaten Bekasi [tesis]. Jakarta (ID): Universitas Indonesia. 
Evianto E. 2010. Analisis Disparitas IPM Kabupaten/Kota di Provinsi Jawa Barat dan Faktor-faktor yang mempengaruhinya. Jakarta (ID): Universitas Indonesia.

Gujarati D. 2005. Ekonometrika Dasar, Alih Bahasa Soemarno Zein, Jakarta: Erlangga.

Juanda B, Junaidi. 2012. Ekonometrika Deret Waktu. Teori dan Aplikasi. Bogor: IPB Pr

[KemenPPPA]

Kementerian Pemberdayaan Perempuan dan Perlindungan Anak. 2014. Laporan Pembangunan Manusia Berbasis Gender. Jakarta (ID): Kementerian PPPA

Klasen S, Lamanna F. 2009. The Impact of Gender Inequality in Education and Employment on Economic Growth. Feminist Economics 15(3): 91-132.

Kuncoro M. 2004. Otonomi dan Pembangunan Daerah. Jakarta: Erlangga.

Meylina A, Nikensari I, Kuncara H. 2013. Pengaruh pengeluaran Pemerintah Daerah pada Sektor Pendidikan dan Kesehatan terhadap IPM di Indonesia. Jurnal Ekonomi dan Bisnis. Vol 1 No 1.

Pito AH. 2013. Tantangan Terkini Pembangunan Daerah. Jurnal Pembangunan Daerah 3(3):27-41.

Prasetyo AD, Zuhdi U. 2013. The Government Expenditure Efficiency toward the Human Development. Procedia Economics and Finance 5:615-622.

Rangkuti F. 1997. Analisis SWOT Teknik Membedah Kasus Bisnis. Jakarta (ID): Gramedia.

Ranis G.2004. Economic Growth and Human Development. Yale University.

Situmorang DMS. 2011. Penentuan Prioritas Pembangunan Berdasarkan Potensi dan Tingkat Perkembangan Kecamatan di Kota Depok [tesis]. Bogor (ID): Institut Pertanian Bogor.

Suri T, Boozer MA, Ranis G, Stewart F. 2011. Path to success: The Relationship between Human Development and Economic Growth. World Development Vol 39 No 4: 506-522. doi:10.1016/j.worlddev.2010.08.020.

Tadjoeddin MZ, Suharyo WI, Mishra S. 2001. Aspirasi terhadap ketidakmerataan. Disparitas regional dan konflik vertical di Indonesia. Working Paper: 12/01/02-1. Jakarta: UNSFIR.

Ulengin F, Kabak O, Onsel S, Aktas E, Parker BR. 2011 .The Competitiveness of Nations and Implications for Human Development. EPS Journal 45.1:1637. 